\title{
Management of PCOS Through Shodhana (Bio-Purification) A Panchkarma Modality- A Single Case Study.
}

\author{
* Sharma Sangeeta ,** Mangal Gopesh, $* * *$ Sharma Sushila, ****Dr Surya Prakash \\ * PhD Scholar, Department of Panchkarma, NIA, Jaipur, India. \\ ** Assistant Professor \& Head(I/C), Department of Panchkarma, NIA, Jaipur, India. \\ *** Professor, Department of Prasuti Tantra and Striroga, NIA, Jaipur, India.
}

\begin{abstract}
:
Polycystic Ovarian Syndrome is a endocrinological disease of women in reproductive age. Its prevalence is around 5-10\% world wide. Oligomenorrhea, weight gain, hirsuitism, anxiety and depression are some the symptoms of PCOS. It can be compared to Arthavakshaya in specific and Bahudoshavastha in general. It is a case study of a female patient aged 27 years, who presented with complains of PCOS since five years, associated with increased TSH levels and increased lipid profile. She took both allopathy and homeopathy treatment but could not find the result, so approached NIA, Jaipur for management. Looking into the severity,Sanshodhana that is Vamana and Virechana was planned for the patient. After Shodhana, there was reduction in the ovarian volume and number of non dominant follicles in USG .TSH and Lipid profile came to normal. Symptomatically also patient had relief in her symptoms along with five $\mathrm{kg}$ wt reduction.
\end{abstract}

Key words: Menstrual disorder, Panchkarma, Hypothyroidism, Shodhana, Artavadosha, Bio-purification.

\section{Introduction}

PCOS is probably fastest growing health hazard amongst women of reproductive age. The prevalence of this disease in general population is about $5-10 \%$ worldwide. ${ }^{[1]}$

It is considered as most common endocrinological disease. Sedentary lifestyle, stress are contributing factors in its increasining prevalence. Clinical presentation of this disease varies widely. Polycystic ovarian syndrome is mainly charecterised by Hyperandrogenism, chronic anovulation and polycystic ovaries. Menstrual disturbances commonly observed in PCOS are oligomenorrhea, amenorrhea and prolonged erratic menstrual bleeding. ${ }^{[2]}$ The complications associated with PCOS are menstrual irregularities, infertility, obesity, Endometrial hyperplasia, insulin resistance, anxiety and depression. The allopathy treatment is hormonal therapy and other drugs which cause many adverse effects in due course of time.

In Ayurveda there is no direct reference of PCOS. It is a endocrinological disease involving many systems. Depending upon the symptoms it is Bahudoshavastha condition. Looking into the Dosha condition, the symptoms are more of kapha and Vata vitiation. Kapha gets vitiated causing Srotoavarodha and leading to Vata Vaigunyata. As oligomenorrhea is the most common symptoms it can also be compared to Artavakshaya told by Acharya Sushruta, and the management told is Sanshodhana and Agni Vardhaka Chikitsa. ${ }^{[3]}$

\section{Case report:}

A female patient of age 27 years, already diagnosed with PCOS and Hypothyroidism admitted in IPD of National Institute of Ayurveda on with registration number 2724 in Prasuti Tantra and Strirog department. She had been referred to dept. of Panchkarma for management. Patient was suffering with Hypothyroidism since 2010 and PCOS since 2013. She was taking Eltroxin $100 \mathrm{mcg}$ since 5 years and also irregular Allopathy and Homeopathy management for PCOS since 5 years. So there was a history of around seven years. She presented with complains of delayed mens trual cycle, constant weight gain mainly central obesity ,hair growth on face (Hirsuitism) and maximum associated symptoms of PCOS and Hypothyroidism. Along with these she had complaint of passing stool for10 to 12 times per day, suggestive of incomplete 
Sharma Sangeeta , International Journal of Ayurvedic\& Herbal Medicine 7(6) Nov.-Dec. 2017 (29763-2976)

defecation, acidity, flatulence, disturbed sleep and heaviness in the body.USG was also suggestive of Polycystic ovarian disease. After complete examination, blood investigations were done, which revealed increased TSH and Lipid profile.

\section{Observations:}

Patient is heavy built with $80 \mathrm{kgs}$ weight, more fat around abdomen.

Hair was seen on face. Dull and lethargic look.

Prakriti-kapha vata

Bala-Madhyama

Agni-Mandagni

Koshta-krura.

\section{Treatment:}

The clinical condition of the patient was suggestive of Bahudoshavastha condition. So Sanshodhana was planned for the correction of underlying pathology. Both Vamana Karma followed by Virechana Karma was done.

\section{Vamana Karma:}

Deepana Pachana: Panchkola churna given for 3 days before food with luke warm water.

Abhyantara Snehapana: done with Shuddh Go Ghrita for six days in Arohana krama (Escalating dose), started with $30 \mathrm{ml}$.

$\begin{array}{lll}\text { First Day } & - & 30 \mathrm{ml} \\ \text { Second Day } & - & 60 \mathrm{ml} \\ \text { Third Day } & - & 100 \mathrm{ml} \\ \text { FourthDay } & - & 150 \mathrm{ml} \\ \text { Fifth Day } & - & 180 \mathrm{ml} \\ \text { Sixth Day } & - & 200 \mathrm{ml}\end{array}$

Samyak Snigdha lakshana are observed on sixth day, like Adhasthat Sneha Darshana, Deeptagni, Snigdha varchas. Seventh day Vishram kala is considered as Vishram kala. Sarwang Abhyanga and Swedan is done and Kaphavardhak Ahara is given like Food particles made of milk, curd, tila, Guda, Masha etc. On Eighth day Vamana Karma was planned. Early morning Sarwang Abhyanga and Swedan was done. Yavagu and Ksheer pan was done and Vamak yoga is given .Vamaka yoga was Madanphala sheeta kashaya made of Madanphala churna $6 \mathrm{gm}$ and Madhuyashtiphant $100 \mathrm{ml}$ Madhu quantity sufficient, Saind hava lavan $2 \mathrm{gm}$. Madhuyashtiphanta and Saindhavodak was given as Vamanopaga Dravya. Madhyam Shuddhi was observed and Pittant vamana was observed that is bile is observed in the vomitus.

Sansarjana krama: After cessation of vomiting, patient was advised to take rest and drink warm water only. In the evening thin rice gruel was given as a food and special diet is advised for next five days as follows in Table no 1.

Table no.1 Sansarjana krama

\begin{tabular}{|l|l|l|}
\hline Day & Morning & Evening \\
\hline 1 & ------------------------ & Liquid portionof the gruel (Peya) \\
\hline 2 & Liquid portion of the gruel (Peya) & $\begin{array}{l}\text { Gruel with little solid portion added with small } \\
\text { amount of salt and ghee. } \\
\text { (Vilepi) }\end{array}$ \\
\hline 3 & $\begin{array}{l}\text { Gruel with little solid portion added with small } \\
\text { amount of salt and ghee.(Vilepi) }\end{array}$ & Green gram soup (AkritaYusha) \\
\hline 4 & Green gram soup (Krita Yusha) with salt and ghee. & Rice with green gram soup, salt and ghee. \\
\hline 5 & Rice with green gram soup, salt and ghee. & Normal diet \\
\hline
\end{tabular}


Sharma Sangeeta , International Journal of Ayurvedic\& Herbal Medicine 7(6) Nov.-Dec. 2017 (29763-2976)

After Sansarjana krama blood investigations were done. Virechan Karma was planned after Sansarjana Krama. Abhyantara Snehapan was done with Shuddh Go Ghrita for three days in escalating dose as $50 \mathrm{ml}$, $100 \mathrm{ml}$ and $150 \mathrm{ml}$. Sarwang Abhyang and Swedan done for three days in Vishram Kala along with Amla Rasa Pradhanata in the diet.

Virechan Yoga: On fourth day after Sarwang Abhyang and Swedan, in Pitta kala around 10 am, 40 gms Trivrit Avaleha was given with luke warm water. Patient was kept under observation. After 40 min. purgation started. patient had 13 episodes of loose motions. Samyak Shuddhi lakshana were observed. It was kaphant Virechan. Sansarjana Krama was planned for five days as mentioned above. Patient had lightness in the body.

Observations and Results:

Weight: Before Treatment $\quad: 80 \mathrm{~kg}$

After Treatment $:: 75 \mathrm{~kg}$

Height of the patient $: 150 \mathrm{~cm}$

BMI: $\quad$ Before Treatment $\quad: 35.55 \mathrm{~kg} / \mathrm{m}^{2}$

After Treatment $\quad: 33.33 \mathrm{~kg} / \mathrm{m}^{2}$

Results of investigations of before and after treatment were mentioned in the table no 2.

Table no.2 Investigation results before and after treatment.

\begin{tabular}{|l|l|l|l|}
\hline INVESTIGATIONS & BEFORE TREATMENT & AFTER VAMANA & AFTER VIRECHANA \\
\hline T3 & $1.8 \mathrm{ng} / \mathrm{ml}$ & $1.7 \mathrm{ng} / \mathrm{ml}$ & $1.9 \mathrm{ng} / \mathrm{ml}$ \\
\hline T4 & $9.0 \mathrm{ug} / \mathrm{dl}$ & $12.0 \mathrm{ug} / \mathrm{dl}$ & $10 \mathrm{ug} / \mathrm{dl}$ \\
\hline TSH & $13.7 \mathrm{Uiu} / \mathrm{ml}$ & $2.5 \mathrm{uIU} / \mathrm{ml}$ & $0.6 \mathrm{Uiu} / \mathrm{ml}$ \\
\hline S.Cholesterol & $510 \mathrm{mg} / \mathrm{dl}$ & $328 \mathrm{mg} / \mathrm{dl}$ & $201 \mathrm{mg} / \mathrm{dl}$ \\
\hline S.Triglycerides & $274 \mathrm{mg} / \mathrm{dl}$ & $287 \mathrm{mg} / \mathrm{dl}$ & $207 \mathrm{mg} / \mathrm{dl}$ \\
\hline HDL & $57 \mathrm{mg} / \mathrm{dl}$ & $54 \mathrm{mg} / \mathrm{dl}$ & $52 \mathrm{mg} / \mathrm{dl}$ \\
\hline LDL & $398 \mathrm{mg} / \mathrm{dl}$ & $216.6 \mathrm{mg} / \mathrm{dl}$ & $107.6 \mathrm{mg} / \mathrm{dl}$ \\
\hline VLDL & $54 \%$ & $57.4 \%$ & $41.4 \%$ \\
\hline
\end{tabular}

Ultrasonography report before and after treatment:

The main change observed in the report was, decrease in the number of non dominant follicle and ovarian volume.

Uterus is normal in shape, size and contour, other details of USG are given in table no. 3.

Table no.3 USG findings before and after treatment.

\begin{tabular}{|l|l|l|l|l|}
\hline \multicolumn{1}{|c|}{$\begin{array}{c}\text { NO. OF } \\
\text { FOLLCLES }\end{array}$} & \multicolumn{2}{|c|}{ RIGHT OVARY } & \multicolumn{2}{c|}{ LEFT OVARY } \\
\hline & BEFORE TREATMENT & AFTER TREATMENT & \multicolumn{1}{c|}{ BEFORE } \\
TREATMENT & AFTER TREATMENT \\
\hline $\begin{array}{l}\text { Number \& } \\
\text { size of DF }\end{array}$ & NO DF SEEN & NO DF SEEN & NO DF SEEN & NO DF SEEN \\
\hline $\begin{array}{l}\text { Number of } \\
\text { NDF }\end{array}$ & $18-20$ & $15-17$ & $12-14$ & $9-11$ \\
\hline $\begin{array}{l}\text { Diameter of } \\
\text { NDF }\end{array}$ & $3-8 \mathrm{~mm}$ & $3-6 \mathrm{~mm}$ & $4-7 \mathrm{~mm}$ & $3-9 \mathrm{~mm}$ \\
\hline $\begin{array}{l}\text { Ovarian } \\
\text { Size }\end{array}$ & $4.9 \mathrm{~cm} \times 1.6 \mathrm{~cm} \times 3.4 \mathrm{~cm}$ & $3.9 \mathrm{~cm} \times 1.7 \mathrm{~cm} \times 3.3 \mathrm{~cm}$ & $4.0 \mathrm{~cm} \times 1.5 \mathrm{~cm} \times 3.6 \mathrm{~cm}$ & $3.8 \mathrm{~cm} \times 1.7 \mathrm{~cm} \times 3.3 \mathrm{~cm}$ \\
\hline $\begin{array}{l}\text { Ovarian } \\
\text { Volume }\end{array}$ & Volume $=14.4 \mathrm{cc}$ & Volume $=13.2 \mathrm{cc}$ & Volume $=11.7 \mathrm{cc}$ & Volume $=10.7 \mathrm{cc}$ \\
\hline $\begin{array}{l}\text { Ovarian } \\
\text { Stroma }\end{array}$ & Echogenic & Echogenic & Echogenic & Echogenic \\
\hline
\end{tabular}


DF-Dominant Follicle, NDF-Non Dominant Follicle

Symptomatically patient had complete relief in the previous complains of acidity, flatulence. After Shodhana her sleep quality has improved, she had disturbed sleep previously. Her previous complain of increased frequency of stool has decreased. General body condition has improved and energy level has improved.

\section{Discussion:}

As there is no direct reference of PCOS in our classics, depending upon the symptoms it can be correlated to Arthavakshaya as delayed menstruation is one of the main symptoms observed. The symptoms of PCOS can also be compared to Bahudoshavastha. ${ }^{[4]}$

Shown in table no.4.

Table no. 4 Comparis on of symptoms of PCOS with Bahudoshavastha.

\begin{tabular}{|l|l|}
\hline PCOS & Bahudosha \\
\hline Weight gain & Sthoulya \\
\hline Acne & Pidika \\
\hline Depression & Avasada \\
\hline Feeling of tiredness & Klama \\
\hline Lack of enthusiasm & Alasya \\
\hline Infertility & Klaibya \\
\hline
\end{tabular}

In Arthavakshaya Sanshodhana and Agnivardhaka Chikitsa was advised by Acharya Sushruta. In Bahudoshavastha also Sanshodhana is the main line of treatment. Chakrapani has commented on Acharya Sushruta,as Sanshodhana here is both Vamana and Virechana. [5]So Vamana followed by Virechana is planned. It is Kapha Vata Pradhana condition associated with Agnimandavastha.

Both the procedures, Vamana and Virechana are bio cleansing in nature. They remove the metabolic waste, accumulated toxins and vitiated Dosha from the body. Thus they help in regularising the disturbed hormonal levels in the body. Vamana and Virechana also work on liver metabolism thus correcting the disturbed lipid levels. Sanshodhana works on correcting the internal pathology. After Shodhana the changes in the USG, as reduction in the ovarian volume and decrease in number of non dominant follicles are positive changes. This shows that there is correction at hormonal level after Shodhana.

\section{Conclusion:}

PCOS is a endocrinological metabolic disorder, resulting due to faulty lifestyle and stress. It can be compared to Arthavakshaya.Sanshodhana can be better line of management for PCOS, as it works on correcting the underlying root cause and treat the disease after detoxification of the body patient has to be advised to follow healthy life style.

\section{References:}

1. Ehrmann DA. Polycystic ovarian syndrome. N Engl j med 2005; 352: 1223-1236.

2. Farquhar C. Introduction and history of polycystic syndrome,In:Kovacs G.Norman R, editors. Polycystic Ovary Syndrome. $2^{\text {nd }}$ ed. Cambridge,UK: Cambridge university Press; 2007.pp. 4-24.

3. Vaidya Jadavji trikamji Acharya,Sushruta Samhita of Susruta with the Nibandasangraha commentary of sri Dalhanacharya, published by chaukambha Sanskrit sansthan Varanasi,reprint edition 2013,Sutra sthana $15^{\text {th }}$ chapter,shloka no12,pg no.70.

4. Dr. G. Shrinivasa Acharya, Panchakarma Illustrated, Chaukhamba Sanskrit Pratishthan, Delhi, Published 2013, Panchakarma Page no. 12.

5. Chakrapani dutta sushruta-sanhita ,sutra sthana with bhanumati commentary, edited by Vaidya jadavji Trikamji Acharya and pt.Nandkishor Sharma Bhishagacharya ,Published by Pt.Shyamsundar Sharma, M.A.,Registrar Agra University and sec,Swami lakshmi Ram trustatNirnaya sagar press, Bombay,first edition 1939, chapter 15,shloka no.12,Pg no.115. 